\title{
ELEKTABILITAS PARTAI DEMOKRAT DALAM PEMILUKADA DI PAPUA BARAT TAHUN 2013
}

\author{
Fitiriani Sari Handayani Razak ${ }^{1}$ \\ 1Program Magister Politik Pemerintahan Fakultas Ilmu Sosial dan Ilmu Politik \\ Universitas Gadjah Mada Yogyakarta \\ Jl. Sosio Yustisia No. 1. Bulaksumur, Yogyakarta, Indonesia 55281 \\ Telp. (0274)563362 ext. 111. Fax. (0274)563362 ext. 222 \\ fitriani90@ymail.com
}

\begin{abstract}
This paper wants to strengthen the general argument has been that the image of political parties less able to explain the results of the victory of candidates promoted by political parties, but the capabilities of personal and political network of candidates in the election victory into a decisive factor. In this study using a literature review in the process of making the necessary data. As a result the Democrats see elektabilitas dynamics in various regions as a comparison taste voters during the elections (local elections). In analyzing the victory of the Democratic candidate in West Papua to use a rational perspective in reading the electoral process. In addition, the implementation of a camshaft that is characteristic of the people of Papua in the electoral process is dilematisasi for the prospective head region in mobilizing the masses.
\end{abstract}

Keywords: elektabilitas, noken system, election

\begin{abstract}
ABSTRAK
Tulisan ini ingin menguatkan argumentasi umum selama ini bahwa citra partai politik kurang bisa menjelaskan hasil kemenangan kandidat yang diusung oleh partai politik, melainkan kapabilitas personal dan jaringan politik kandidat dalam pemilukada menjadi faktor penentu kemenangan. Dalam penelitian ini menggunakan metode tinjauan pustaka dalam proses pengambilan data yang diperlukan. Alhasil dengan melihat dinamika elektabilitas partai demokrat di berbagai daerah sebagai perbandingan selera pemilih pada saat pilkada (pemilihan kepala daerah). Dalam menganalisa kemenangan kandidat partai demokrat di Papua Barat digunakan perspektif rasional dalam membaca proses pilkada. Selain itu, diterapkannya sistem noken yang menjadi ciri khas rakyat papua dalam proses pemilihan merupakan dilematisasi bagi para calon kepala daerah dalam memobilisasi massa.
\end{abstract}

Kata kunci: elektabilitas, sistem noken, pilkada 


\section{A. PENDAHULUAN}

Berbagai konflik yang bergejolak pasca pilkada yang terkadang berakhir di meja MK (Mahkamah Konstitusi), tidak terlepas adanya pengaduan terhadap berbagai kecurangan yang disinyalir dilakukan oleh calon-calon tertentu. Penyimpangan yang terjadi dianggap sebagai pemicu menurunnya tingkat kepercayaan masyarakat terhadap partai tertentu. Untuk itu, dalam mendapatkan atau mempertahanan kepercayaan masyarakat sebagai upaya mempertahankan elektabilitas partai dibutuhkan berbagai strategi serta dengan melemparkan isu atau janji demi mewujudkan kesejahteraan masyarakat.

Pilkada secara langsung yang diterapkan pasca reformasi sebagai bentuk euphoria masyarakat Indonesia. Meski dilaksanakan pemilihan secara langsung oleh masyarakat justru melahirkan 2 kubu masyarakat. Yakni kubu yang optimis dan pesimis, kubu optimis meyakini adanya pemilihan lansung kepala daerah lebihh mendekatkan antara pemilih dan calon kepala daerah, sebelumnya kepala daerah dipilih melalui DPRD dan pasca ditetapkan otonomi daerah masyarakatlah yang memilihh sendiri pemimpin daerah. Para calon kepala daerah melakukan pendekatan dengan masyarakat melalui sosialisasi pada saat kampanye, sehingga masyarakat bisa memilihh kepala daerah yang mampu mewujudkan kesejahteraan masyarakat.

Di sisi lain kubu pesimis menyatakan bahwa adanya pemilihan langsung kepala daerah identik dengan mewabahnya money politic yang sering digunakan para elit dalam memobilisasi massa. Money politics ini baik berupa pemberian uang tunai, sembako dan lain-lain kepada masyarakat. Selain maraknya money politic kurangnya sosialisasi KPUD terhadap masyarakat hingga ke pelosok berpengaruh terhadap tingkat pengetahuan masyarakat mengenai pemilihan langsung yang melahirkan sikap apatis masyarakat.

Terlepas dari dampak pilkada secara langsung yang melahirkan kecemasan dan harapan bagi masyrakat, partai politik semakin berusaha untuk memobilisasi massa di setiap daerah dengan mencalonkan kandidat mereka untuk berkontestasi dalam pilkada di masing-masing daerah. Hal ini sebagai langkah awal dalam mengantongi suara menuju pilpres dan pileg 2014 mendatang.

Namun berbagai kasus yang tengah dihadapi oleh beberapa partai terutama partai demokrat berdampak pada elektabilitas partai ini. Sehingga sangat berpengaruh bagi para kandidatnya yang mencalonkan dalam pilkada di berbagai daerah yang telah dilaksanakan. Meski di sejumlah daerah partai ini (baca: Partai Demokrat) turun pamor, tetapi berbeda yang terjadi pada pemilukada di Papua Barat yang digelar pada 13 Februari 2013 lalu, ditengah menurunnya elektabilitas partai demokrat justru kandidat yang diusung oleh partai ini mendapatkan kemenangan. Pasca reformasi dan diberlakukan adanya pemilihan secara langsung, partai demokrat tetap mempertahankan eksistensinya di Papua Barat. Pada pilkada tahun 2006 yang lalu kandidat yang diusung oleh partai ini (baca: demokrat) mendapatkan kemenangan baik yakni Barnabas Suebu, hal ini tentunya hal yang wajar mengingat partai demokrat sebagai partai pemenang di tingkat nasional. Namun menjelang pemilihan legisltatif dan presiden elektabilitas partai ini mengalami penurunan, tentunya dalam mempertahankan kepercayaan pemilih partai ini memiliki strategi dalam memobilisasi massa baik 
melalui kontestasi kandidat mereka dalam meraih kemenangan dalam pemilukada. Sebagaimana yang terjadi di Papua Barat partai ini berhasil membawa kandidatnya memperoleh suara terbanyak.

Berdasarkan uraian pendahuluan diatas, maka tulisan ini hendak menjawab rumusan masalah yakni: "Bagaimana strategi kandidat yang diusung oleh partai Demokrat dalam memobilisasi massa pada pilkada di Papua Barat Barat tanggal 13 Februari 2013?

\section{B. KERANGKA KONSEP}

Pada saat pemilu, seorang pemilih yang merasa bahwa kondisi ekonomi keluarga atau ekonomi nasional lebih baik dibandingkan tahun sebelumnya, akan memilih calon atau partai yang sedang berkuasa (incumbent), sebaliknya bila ia merasa keadaan ekonomi lebih buruk dibandingkant ahun sebelumnya, maka ia tidak akan memilih incumbent tersebut (Downs, 1957; Kiwiet, 1985).

Adapun pilihan politik didorong oleh kepentingan ekonomi pemilih. Dimana motif ekonomi adalah motif yang paling utama dibandingkan motifmotif lain. Pemilih akan memilih calon itu, ketika sang pemilih merasakan hal itu menguntungkan atau memenuhi keinginan pemilih sendiri.

Menurut Downs, 1957: Pemilih tidak akan memilih calon tersebut bila dinilai merugikannya. Rasionalitas pemilih berkaitan dengan 2 isu yakni: (1) Isu Simbolik atau identitas yang berkaitan dengan identitas kelompok sosial yang maknanya bersifat intrinsik dan asali (bawaan), bukan inskrumental, dan hanya bermakna bagi kelompok bersangkutan. Misalnya isu agama, suku dan kedaerahaan; dan (2) Isu teknis, lebih bersifat rasional dalam pengertian bahwa ada dan tidak adanya kuantitas dan kualitas mendesak atau tidk mendesaknya, penting atau tidak pentingnya, dinilai dari pertimbanganpertimbangan yang masuk akal yakni sebuah kekuatan manusiawi yang dimiliki oleh semua warga apa pun latar belakang identitasnya.

Pada saat pemilu, seorang pemilih yang merasa bahwa kondisi ekonomi keluarga atau ekonomi nasional lebih baik dibandingkan tahun sebelumnya, akan memilih calon atau partai yang sedang berkuasa (incumbent), sebaliknya bila ia merasa keadaan ekonomi lebih buruk dibandingkant ahun sebelumnya, maka ia tidak akan memilih incumbent tersebut (Downs, 1957; Kiwiet, 1985).

Lebih lanjut Kiwiet (1985) menyatakan bahwa evaluasi terhadap kondisi ekonomi nasional adalah predikatorr yang lebih baik dibbandingkan kondisi ekonomi rumah tangga untuk menjelaskan perilaku memilij, karena pemilu atau pilpres lebih berkaitan dengan kepentingan kolektif (sociotropic) ketimbang kepentingan individual penlih secara langsung (egotopic).

Lebih lanjut menurut saiful mujani, dkk (2011) tiga pendekatan perilaku pemilih dalam menentukan pilihannya antara lain: (1) Sosiologis (Columbia Study), (2) Psikologis (Michigan Model), dan (3) Pilihan Rasional (rational choice). Keanekaragaman masyarakat Indonesia tentunya ketiga model perilaku pemilih berkaitan dalam menentukan pilihannya masing-masing (Baca: pemilih) di setiap daerah.

\section{HASIL DAN PEMBAHASAN}

Pilkada langsung di Papua Barat sudah 2 kali dilaksanakan pasca reformasi yakni pada tahun 2006 dan 2013. Dalam pelaksanaan pilkada, pemilih biasanya memilih kandidat dari latar belakang partai politik yang mengusungnya serta kapabilitas dari 
kandidat itu sendiri. Pemilih di Papua Barat dapat dikategorikan sebagai pemilih yang tidak terpengaruh akan elektabilitas partai. Hal ini tercermin dari kemenangan yang diperoleh kandidat yang diusung oleh partai demokrat ditengah merosotnya elektabilitas partai ini. Di tahun 2006 pun kandidat yang diusungnya (Baca: partai demokrat) yakni Barnabas Suebu berhasil memenangkan kontestasi pilkada Papua Barat tersebut, selanjutnya pada pilkada yang diadakan pada 13 Februari 2013 Lukas Enembe berhasil mendapatkan suara terbanyak. Meski perolehan suara partai demokrat pada tahun 2009 di Papua Barat Barat berada pada urutan kedua setelah partai Golongan Karya (http://www.media center.kpu.go.id/hasil-pemilu-2009454hasil-perolehan-suara-partai-politik-diPapua-barat.html.)

Berdasarkan hasil perolehan suara partai politik di tahun 2009 dan berdasarkan survei yang baru-baru ini dilakukan oleh Lingakran Survei Indonesia (LSI) menyatakan bahwa dukungan masyarakat terhadap Partai Demokrat semakin menurun sejak munculnya berbagai kasus di permukaan, seperti kasus dugaan suap wisma atlet SEA Games yang menyeret beberapa nama kader partai biru ini. Mulai dari Nazaruddin, Angelina Sondakh, Andi Malarangeng (mantan Menpora), hingga akhirnya disusul oleh mantan Ketua Umum partai demokrat sendiri yakni Anas Urbaningrum. Prahara politik tengah dihadapi oleh partai demokrat tercermin adanya beberapa kandidat PD di berbagai daerah kalah dalam pilkada. Fenomena ini sebagai cambuk bagi politisi demokrat untuk meningkatkan elektabilitasnya yang tengah menurun. Berbagai kasus yang melibatkan kader partai demokrat ini memberi dampak terhadap tingkat kepercayaan masyarakat saat ini.
Sebagai partai yang dibina oleh Presiden RI ini dikalahkan oleh Partai Golkar dan PDI-Perjuangan sebagaimana ditunjukkan survei nasional. Pada Juni 2011, Demokrat berada di posisi kedua setelah partai Golkar. Sedangkan pada Februari 2012, merosot ke posisi ketiga dengan perolehan suara hanya $13,7 \%$ setelah Golkar (18,9 \%) dan PDI-P (14,2 \%). Survei LSI ini dilakukan 21 Januari 2011 hingga 2 Februari 2012 dengan melibatkan 1.200 responden dari 33 provinsi di Indonesia. Metode yang digunakan adalah multi stage random sampling yang dilengkapi dengan focus grup discussion di 7 ibukota terbesar di provinsi dan analisa kualitatif lainnya. Adapun tujuh ibukota tersebut adalah Medan, Bandung, Jakarta, Tangerang, Surabaya, Semarang, dan Palembang. Dengan kemungkinan "Margin of error plus minus sebesar 2,9 \% (http://www.pemilunews.com/index.p hp/2012/02/10/partai.468-survei-lsidemokrat-turun-tahta-ke-posisi-3.html)

Tidak cukup sampai disitu, elektabilitas partai Demokrat kian menurun di tahun 2012. Berdasarkan hasil survei yang dilakukan oleh Center for Strategic and Internasional Studies (CSIS) di 31 provinsi dengan melibatkan 1.635 responden, menunjukkan adanya kemelorotan elektabilitas terhadap partai Demokrat yang kini menduduki urutan nomor empat dengan angka $7,1 \%$ pasca berhentinya Anas Urbaningrum selaku Ketua Umum Partai tersebut.

Hasil survey diatas tentunya berimplikasi terhadap para kandidat yang mencalonkan untuk berkontestasi dalam pilkada di berbagai daerah. Seperti yang terjadi di Sulawesi Selatan, Jawa Barat dan Sumatera Utara dimana kandidat yang diusung oleh partai demokrat ini mengalami kekalahan. Beberapa media memberitakan bahwa 
salah satu faktor yang menyebabkan kekalahan oleh pasangan Dede-Lex pada pilkada Jabar karena kasus yang tengah dihadapi oleh partai pengusungnya.

Namun berbeda yang terjadi di Papua Barat, elektabilitas partai demokrat tidak berpengaruh atas pencapaian pasangan Lukas EnembeKlemen Tinal yang menang pada pilkada di Papua Barat untuk periode 20132018. Meski di daerah lain kandidat yang diusung partai biru ini mengalami kekalahan justru di Papua Barat kandidat yang diusung oleh partai ini mengalami kemenangan. Kemenangan yang diperoleh tentunya dikarenakan beberapa faktor eksternal maupun internal dari kandidat secara personal dan strategi partai demokrat secara umumnya.

\section{Perspektif Rasionalitas Pemilih}

Dinamika kekuatan partai politik yang terjadi di Indonesia termasuk Papua Barat Barat tidak mampu dijelaskan melalui pendekatan sosiologis dan prsikologi. Karena dari sisi pemilih di Papua Barat Barat justru belum memiliki ID Party yang jelas dalam suatu komuitas masyarakatnya. Ditambah kondisi geografis yang sulit terjangkau untuk diadakan sosialisasi mengenai pengetahuan politik dan partai politik, baik pihak KPUD dan media pun terkadang absen menyentuh masyarakat hingga ke pedalaman. Oleh karena itu dalam menjelaskan kasus kemenangan Lukas Enembe sebagai kandidat yang diusung oleh partai demokrat ini dianalisa dengan menggunakan model pilihan rasional, dimana pemilih cenderung memilih partai ataupun kandidat yang berkontestasi dalam pilkada berdasarkan asumsi kepentingan atau keuntungan yang diperoleh pada saat memberikan dukungannya.
Di tengah menurunnya tingkat elektabilitas partai demokrat di masyrakat, hal ini tidak berpengaruh pada kandidat partai biru ini dalam berkontestasi di pemilukada Papua Barat yang dilaksanakan pada tanggal 13 Februari 2013. Meski didaerah lain elektabilitas berpengaruh terhadap perolehan suara kandidatnya, namun berbeda dengan yang terjadi di Papua Barat justru pasangan Lukas EnembeKlemen Tinal kandidat partai demokrat ini justru memperoleh kemenangan dengan perolehan suara $52 \%$ lebih (http://regional.kompas.com/read/201 3/03/11/22033657/)

Namun kemenangan tersebut diikuti adanya laporan dari kelima pasangan yang kalah ke MK dengan dugaan penyimpangan dan kecurangan yang terjadi pada proses pemilu. Pelanggaran yang terjadi diduga dilakukan secara terstruktur, bersifat massif dan sistematis. Laporan adanya dugaan pelanggaran pada proses pemilu yang ditujukan pada pasangan Lukas Enembe-Klemen Timal ditolak oleh MK karena tidak adanya bukti yang kuat atas pelanggaran seperti yang dilaporkan.

Kemenangan yang diperoleh pasangan Lukas Enembe-Klemen Timal yang diusung partai demokrat ini sebagai salah satu fenomena yang menggelitik, dimana tingkat elektabilitas partai ternyata tidak berpengaruh atas perolehan suara kandidat dalam berkontestasi di daerah. Dengan menggunakan pendekatan rasional dalam melihat kemenangan Lukas Enembe-Klemen Tinal sebagai pasangan yang diusung partai demokrat. Namun dalam tulisan ini cenderung melihat partai demokrat menggunakan Lukas Enembe sebagai kendaraan politik dalam memobilisasi massa di Papua Barat menuju pemilihan legislatif dan pilpres 2014. 
Sosok Lukas Enembe dikenal sebagai orang yang aktif bersosialisasi dengan masyarakat, karena pernah menjabat sebagai penggerak kegiatan kelompok tani di pegunungan tengah. Selain itu dia (baca: Lukas Enembe) orang yang mampu berdiplomasi dalam menangani permasalahan yang ada di Papua Barat, seperti menjadi penengah atau perantara pihak OPM dengan Pemerintah dalam proses penyatuan pendapat dan kepentingan dalam menjaga keutuhan NKRI dan mewujudkan kesejahteraan masyarakat.

Selanjutnya model pilihan rasional ini memandang bahwa: "orang memilih calon atau partai apabila calon atau partai tersebut dapat membantu pemilih dalam memenuhi kepentingan dasaranya yakni kepentingan ekonomi" (mujani dkk, 2012:33). Hal ini yang mendasari para kepala suku dan kelompok masyarakat lainnya seperti OPM cenderung memberikan suaranya kepada Lukas Enembe yang dianggap mampu mengakomodasi kepentingan mereka.

\section{Faktor-faktor dalam Mobilisasi Massa}

Pada proses pemilihan tidak terlepas dari faktor geografis dan sosial politik suatu daerah. Sebagai wilayah perbatasan Indonesia, Papua Barat dikenal dengan daerah pegunungan dimana masyarakatnya hidup dengan membentuk komunitas. Masing-masing komunitas memiliki kepala suku sebagai pemimpin mereka.

\section{a. Faktor Geografis}

Untuk melihat proses pemilihan, tentunya berkaitan dengan kondisi geografis suatu daerah. Provinsi Papua Barat terletak antara $2^{\circ} 25^{\prime}-9^{\circ}$ Lintang Selatan dan $130^{\circ}-141^{\circ}$ Bujur Timur. Provinsi Papua Barat yang memiliki luas $317.062 \mathrm{~km} 2$ atau 17,04 persen dari luas Indonesia, merupakan provinsi dengan wilayah terluas di Indonesia.
Pada tahun 2010, Papua Barat dibagi menjadi 28 kabupaten dan 1 kota dimana Merauke merupakan kabupaten/kota terluas (56,84\%) dan Kota Jayapura merupakan kabupaten/kota terkecil di Papua Barat (0,1\%). Papua Barat di bagian utara dibatasi Samudra Pasifik, sebelah selatan berbatasan dengan Laut Arafuru, sebelah barat berbatasan dengan Laut Seram, Laut Banda, Provinsi Papua Barat Barat, Provinsi Maluku dan sebelah timur berbatasan dengan Papua Barat New Guinea(http://papuabarat.bps.go.id)

Pada tahun 2010 jumlah penduduk Provinsi Papua Barat sebanyak 2.833.381 jiwa. Penduduk laki-laki Provinsi Papua Barat sebanyak 1.505.883 jiwa dan perempuan sebanyak 1.327.498 jiwa. Seks Rasio penduduk Papua Barat adalah 113. Sedangkan Total Rasio Ketergantungan (Total Dependency Ratio) di Papua Barat sebesar 56,37 persen, dimana Rasio Ketergantungan Usia Muda (Youth Dependency Ratio) sebesar 54,87 persen dan Rasio Ketergantungan Usia Tua (Aged Dependency Ratio) sebesar 1,50 persen. Artinya, setiap 100 penduduk usia produktif (15-64 tahun) menanggung sekitar 54-55 anak usia 014 tahun dan 1-2 orang lanjut usia (65 tahun keatas) (http://www.papuabarat. bps.go.id)

Keadaan wilayah Papua Barat ini identik dengan pegunungan dengan ketinggian tempat sebagian besar dibawah $500 \mathrm{~m}$ dpl ( \pm 606.400 ha atau $61,01 \%$ ) ketinggian 500-1000 m dpl dan ketinggian $1000-2000 \mathrm{~m}$ dpl ( \pm 149.900 ha atau $15.08 \%$ ). Pegunungan di wilayah Kabupaten Jayapura antara lain pegunungan Cycloop yang terbentang antar Distrik Sentani, Sentani Barat, Sentani Timur dan Depapre disebelah Utara, selain itu disebelah Selatan terdapat pegunungan Kramor di Distrik Kaureh. 
Keadaan topografi dan lereng umumnya relatif terjal dengan kemiringan $5 \% \quad-30 \%$ serta mempunyai ketinggian aktual $0,5 \mathrm{~m} \mathrm{dpl}$ - 1500 m dpl. Daerah pesisir pantai utara umumnya berupa dataran rendah yang bergelombang dengan kemiringan $0 \%-10 \%$ yang ditutupi dengan endapan alluvial. secara fisik, selain dataran juga terdiri dari rawa $( \pm 13,700$ Ha ). sebagian besar wilayah Kabupaten Jayapura (72.09 \%) berada pada kemiringan diatas $41 \%$, sedangkan kemiringan 0-15 \% berkisar 23,74\%.

Aspek geografis inilah yang mempengaruhi pola kehidupan masyarakat Papua Barat Barat baik dalam berkomunikasi dengan manusia yang diluar dari komunitas mereka serta bagaimana dalam memenuhi kebutuhan dasarnya seperti mencari makan, tempat tinggal dan sebagainya. Berdasarkan kondisi geografis dan topografi pedalaman Papua Barat Barat terdiri dari pegunungan dan lembahlembah yang sangat sulit dilalui oleh transportasi darat apapun. Butuh waktu yang sangat lama bagi masyarakat pedalaman untuk sampai ke kota Jayapura, misalnya saja jarak dari kota Jayapura ke kota Wamena dan sekitar puncak Jayak $\pm 2.000 \mathrm{~km}$ ditambah belom adanya transportasi darat yang memudahkan mobilisasi mereka.

Dengan mengacu pada kondisi geografis di Papua Barat yang memiliki hambatan dan tantangan untuk menuju wilayah hingga ke pedalaman, masyarakat lebih cenderung memberlakukan sisten representasi dalam proses pemilihan. Ditambah sistem transportasi yang tentunya membutuhkan biaya yang sangat mahal mengingat wilayah ini sangat terjal dan tinggi untuk menjangkau wilayah pedalaman menggunakan jalur udara (helicopter) karena dengan menggunakan jalur darat tentunya memakan waktu yang cukup lama.
Untuk pada proses pemilihan di Papua Barat, masyarakat cederung menganut sistem representasi dimana kepala suku mewakili suara masyarakatnya. Meski pada demokrasi, dalam pemilihan "one man one vote" di Papua Barat justru tidak berlaku.

Dengan melihat kondisi geografis di Papua Barat, pemilih disana cenderung berperilaku rasional dimana menganggap bahwa orang yang memilih ataupun tidak memilih dalam pemilu tetap aka nada pemimpin politik baik dari kubu manapun, pemilihan dianggap hal yang sia-sia dan membuang tenaga dan waktu saja (mujani dkk, 2012:33). Jadi untuk apa harus rela pergi ke TPS yang jaraknya cukup jauh dari tempat tinggal mereka hanya untuk mengikuti pemilihan sedangkan suara mereka dapat diwakili ke kepala suku mereka.

\section{b. Faktor Sosial Politik}

Perspektif masyarakat yang menyatakan bahwa pemilu hanya memberi keuntungan atas kelompok tertentu atau para elit dan partai saja, menambah implikasi terhadap sikap apatis masyarakat untuk tidak berpartisipasi dalam pemilu dan lebih cenderung memberikan hak suaranya kepada kepala suku sebagai representasi mereka. Ditambah banyaknya aspirasi yang berbeda-beda dari rakyat Papua Barat. Aspirasi itu datang dari kelompok agama, kelompok adat dan suku. Latar belakang kultural, ekonomi, dan pendidikan di Tanah Cendrawasih melahirkan penilaian bahwa demokrasi langsung belum dapat diterapkan seutuhnya.

Mekanisme pemilihan di Papua Barat yang merepresentasikan suara mereka dianggap sebagai hal yang paling demokratis. Model pemilihan tersebut dikenal selama ini dengan istilah Noken. Noken adalah salah satu mekanisme pemilihan yang digunakan oleh masyarakat Papua Barat, baik ditingkatan pemilihan kepala daerah/ 
Pemilukada, Pemilihan Anggota Legislatif, maupun Pemilihan Presiden. Proses pemilihan dengan konsep Noken dilaksanakan dengan model perwakilan, dimana pilihan anggota masyarakat disatu suku atau satu politik terkecil/ komunitas tersebut yang ada diwakili oleh kepala suku. Pilihan politik setiap satu orang atau anggota suku tercermin dari pilihan yang disuarakan melalui kepala suku. Suara tiap orang diakumulasi menjadi menjadi satu, menjadi suara suku atau komunitas tersebut. Namun sebelum kepala suku menentukan pilihan proses kesepakatan melalui musyawarah diantara anggota dan tetuah dalam suku tersebut. Misalnya dalam proses pemilihan seorang kepala daerah tiap suku hanya memilih salah satu kandidat namun jumlah suaranya tetap berdasarkan jumlah wajib pilih dalam suku tersebut.

Mekanisme tersebut dilakukan oleh panitia pemilihan dengan sebelumnya melakukan pendataan jumlah warga yang punya hak pilih disuku tersebut kemudian penentuan suara semua pemilih didasarkan oleh suara kepala suku. Suara kepala suku hanya satu pilihan dan mewakili semua jumlah suara pemilih disuku tersebut. Praktek ini kemudian menjadi problematik ketika dihadapkan pada konsepsi dasar Demokrasi yang dikenal secara umum yang didasarkan pada prinsip One Men, one vote (satu orang, satu suara). Dimana basis Demokrasi (khususnya Demokrasi Liberal) dilatari oleh prinsip bahwa setiap orang warga negara mewakili pilihan politiknya secara langsung dalam proses pemilihan. Hal tersebut secara Filosofis menjadi landasan demokrasi yang mempercayai bahwa tiap individu adalah entitas politik yang bebas, merdeka, dan bertanggung jawab bagi dirinya sendiri. Namun yang terjadi pada kondisi sosial politik di Papua Barat dalam proses pemilihan yang menggunakan sistem noken ini Noken dianggap menjadi upaya meretas konflik yang bisa saja terjadi akibat mekanisme pemilihan yang berbasis secara individual.

Dalam tataran praktis, partisipasi dan pilihan politik tiap warga negara disuarakan secara langsung dan tak bisa diwakilkan dalam proses pemilihan Pemimpin atau wakilnya. Tiap inidividu tidak bisa mewakilkan suaranya oleh orang lain (baik kepada keluarganya, kepala suku atau apapun) dalam pemilu. Selain itu tiap individu juga punya kebebasan penuh menentukan pilihannya tanpa harus mengikuti keinginan mayoritas pilihan suku, kelompok atau komunitasnya.

Dengan sistem noken yang dilakukan pada proses pemilihan, Lukas Enembe-Klemen Tinal senantiasa menjalin hubungan dengan kepala suku sebagai upaya memobilisasi massa. Selanjutnya pemilih pun memiliki kemampuan untuk menilai kandidat yang ada, berdasarkan perspektif rasional terhadap isu politik atau kandidat ini bisa didasarkan pada jabatan, informasi, pribadi yang popular karena prestasi dibidang masing-masing seperti seni, olahraga, film, organisasi, politik dan sebagainya. Bagi masyarakat Papua Barat sosok Lukas Enembe sebagai pribadi yang memiliki jiwa kepemimpinan dan mediator yang baik antara pemerintah dan OPM (Organisasi Papua Barat Merdeka). Selain itu riwayat kariernya pun terbilang cukup diperhitungkan, dimana pernah menjabat sebagai Bupati yang baik dan mampu menjadi mediator ketua-ketua OPM di pedalaman Papua Barat dengan Pemerintah Indonesia.

Lukas Enembe satu-satunya tokoh Papua Barat yang berhasil mendatangi masrkas besar OPM dan sebagai penyalur aspirasi OPM, dengan terpilihnya Lukas Enembe diharapkan kepentingan-kepentingan OPM bisa 
terus terkawal. Serta dapat diselaraskan dengan kepentingan Negara.

\section{PENUTUP}

Menurunnya elektabilitas partai demokrat ternyata tidak berpengaruh atas kemenangan Lukas EnembeKlemen Tinal dalam berkontestasi di Pilkada Papua Barat Barat yang dilaksanakan pada tanggal 13 Februari 2013 kemarin. Berbeda dengan yang terjadi pada pilkada Jawa Barat, menurunnya elektabilitas partai ini berrpengaruh atas perolehan suara pasangan Dede-Lex. Hal ini memberi gambaran bahwa pemilih cenderung memilih kandidat yang diusung oleh partai politik berdasarkan kapabilitas individu sang calon tersebut, bukan berdasarkan pamor partai politik.

Dengan melihat faktor geografis dan sosial politik yang terjadi di Papua Barat Barat, dapat dikatakan bahwa kedekatan antara pemilih dan calonlah yang lebih berpengaruh ketimbang partai demokrat. Kurangnya sosialisasi disebabkan faktor geografis dan topografi yang memiliki banyak hambatan dan tidak didukung oleh transportasi dalam memudahkan jangkauan masyarakat luar dalam berkomunikasi ataupun melakukan sosialisasi dengan masyarakat pedalaman mempengaruhi tingkat pengetahuan masyarakat atas pengetahuan politik apalagi dengan partai politik. Dengan menggunakan perpektif rasional pemilih dalam proses pemilihan masyarakat pedalaman cenderung beranggapan bahwa untuk ikut pemilihan hanya membuang tenaga dan waktu mereka saja untuk itu mereka cenderung mewakilkan suara mereka kepada kepala suku sebagai representasi mereka atau disebut dengan istilah sistem noken.

Model rasional pemilih juga yang member dampak perolehan suara bagi pasangan Lukas Enembe-Klemen Tinal dimana pemilih cenderung memperhatikan kepentingan mereka dalam memberikan pilihannya serta keuntungan-keuntungan yang didapatkan ketika calon yang mereka dukung menang, hal ini bersifat ekonomi. Kandidat terpilih berupaya untuk menciptakan kesejahteraan masyarakatnya serta kemampuannya untuk meredam konflik yang selama ini terjadi di Papua Barat. Baik antar suku maupun gerakan-gerakan separatis oleh OPM. Dengan demikian elektabilitas partai demokrat yang tengah menurun ternyata tidak berpengaruh terhadap perilaku pemilih dalam memilih kader demokrat yang berkontestasi di pilkada Papua Barat Barat.

\section{DAFTAR PUSTAKA}

Asfar, Muhammad. 2006. Pemilu dan Perilaku Memilih 1955-2004. Surabaya. Pustaka Eureka.

Djojosoekarto, Agung \& Rudi Hauter (ed), _, Pemilihan Langsung Kepala Daerah: Transformasi Menuju Demokrasi Lokal, Jakarta , ADEKSI.

Karoba, Sem, dkk. 2004. Papua Barat Menggugat! Bagian Satu: Politik Otonomisasi NKRI di Papua Barat Barat!". Yogyakarta. Watch Papua Barat.

Mujani, Saiful, R. William Liddle \& Kuskridho Ambardi. 2012. Kuasa Rakyat " Analisis Tentang Perilaku Memilih dalam Pemilihan Legislatif dan Presiden Indonesia Pasca-Orde Baru". Jakarta Selatan. Mizan.

Ofm, Theo Van Den Broek, dkk. 2003. Memoria Passionis di Papua Barat "Kondisi Sosial-Politik dan Hak Asasi Manusia 2001. Jakarta. LSPP. 
Pamungkas, Sigit. 2010. Pemilu, Perilaku Pemilih dan Kepartaian. Yogyakarta. Institute For Democracy and Welfarism.

Yuniarti, Fandri \& Chris Verdiansyah (ed). 2007. Ekspedisi Tanah Papua Barat-Laporan Jurnalistik Kompas. Jakarta. Kompas Media Nusantara.

\section{Media Internet}

http://papuabarat.bps.go.id/ Diakses pada tanggal 12 Januari 2015

http://regional.kompas.com/read/2013 /03/11/22033657/. Diakses pada tanggal 12 Januari 2015.

http://www.mediacenter.kpu.go.id/hasi l-pemilu-2009454-hasilperolehan-suara-partai-politikdi-Papua-barat.html. Diakses pada tanggal 12 Januari 2015.

http://www.news.okezone.com.read.20 13/05/27.elektabilitas-anjlokdemokrat-siapkan-strategikhusus.html Diakses pada tanggal 12 Januari 2015.

http://www.pemilunews.com/index.ph p/2012/02/10/partai.468survei-lsi-demokrat-turuntahta-ke-posisi-3.html. Diakses pada tanggal 12 Januari 2015. 